\title{
Brine Solution with Hydrocolloids Used to Enhance the Properties of Sterilized Meat
}

\section{Vinicius Jose Bolognesi' $\odot$, Michele Rigon Spierº and Carlos Eduardo Rocha Garcia' $\odot$}

\section{'Pharmacy Department,} Pharmaceutical Sciences Postgraduate Programme, Federal University of Parana, Lothario Meissner St. 632, 80210-170 Curitiba, Paraná, Brazil

${ }^{2}$ Chemical Engineering Department, Federal University of Parana, Francisco H. dos Santos St., 81530900, Curitiba, Paraná, Brazil

Received: 18 April 2019 Accepted: 21 May 2020
*Corresponding author:

Phone +554133604193;

E-mail: carlos.garcia@ufpr.br

\section{SUMMARY}

Research background. Retort processing is one of the most widely used methods of thermal inactivation that provides convenient, ready-to-eat foods. Although this technology remains widespread, it can be revamped through processing of novel ingredients such as gums. This article aims to investigate the effect of the hydrocolloids collagen, soy protein isolate, carrageenan and modified starch with different salt mass fractions on the retorted meat products.

Experimental approach. Firstly, solutions of the added hydrocolloids of different salt mass fractions in order to stimulate the salting-in effect were studied. Lipid oxidation, syneresis and water activity were analysed during shelf life to find the best overall treatments. Lastly, sensory and texture analyses were then performed to assess the impact of the added hydrocolloids.

Results and conclusions. Yield, cooking loss and water-holding capacity had better results when higher salt mass fractions with hydrocolloids were used. The physicochemical results distinguished collagen from the other tested hydrocolloids. Syneresis remained in similar ranges regardless of the treatment. No difference was observed in water activity either. However, sterilization, vacuum sealing and the addition of a hydrocolloid contributed to low oxidation levels in all treatments. Lastly, sensory, texture and shear force analyses confirmed that the products with collagen were harder and firmer than the control samples, which explains the preference of control samples by the panellists. Nevertheless, assessors did not perceive the presence of collagen.

Novelty and scientific contribution. Physicochemical and sensory characteristics of the retorted meat can be considerably improved when brine and hydrocolloids are combined with the retort technology.

Key words: collagen in meat, lipid oxidation during shelf life, thermal inactivation of readyto-eat foods, water retention

\section{INTRODUCTION}

Sterilization is a widespread technology that can offer meat products with desirable physicochemical and organoleptic parameters (1), the most important being the ability to provide a safe, convenient and ready-to-eat food products (2). However, sterilization under high temperatures affects meat proteins, causing unfolding which leads to a lower binding capacity with water, influencing the texture and flavour, and resulting in yield loss (2-4). Even though several meat products have been successfully developed by retorting, such as meatballs (5) and chicken porridge (6) among others, there is a lack of studies showing the benefit of the use of hydrocolloids with this kind of processing.

Biopolymers have the ability to retain water through their hydrophilic groups and are temperature-dependent. The heating and cooling stages of sterilization instil gelatinization on hydrocolloids, improving, for example, the formation of a resistant starch, viscosity $(7)$ and water retention $(8,9)$. Water can be found in three different forms in the polysaccharide-water systems, i.e. non-freezing, freezing bound and free water. Between the two kinds of bound water, the amount of non-freezing water depends on the chemical 
structure of the polysaccharide matrix. In the case of water-insoluble polysaccharides, the number of hydroxyl groups located in the amorphous region determines the amount of non-freezing water. In contrast, the amount of freezing bound water depends on the higher-order structure of the molecular chain (9).

In order to obtain optimal yield and ensure safety of the retorted meat products, the of the interaction between hydrocolloids and meat under the processing conditions must be investigated $(8,10)$. Therefore, before such a system can be developed and commercialized, it is important to know the behaviour of the additives in meat products (1).

Hence, this work aims to investigate the influence of the individual use of hydrocolloids collagen, soy protein isolate, carrageenan, and modified starch, with different sodium chloride mass fractions on yield, cooking (by retorting) loss, water holding capacity and, subsequently, assess the shelf life by evaluating the parameter of oxidation stability, water activity and syneresis on the sterilized beef.

\section{MATERIALS AND METHODS}

\section{Materials}

Beef muscle (vastus lateralis) was purchased from a local market in Curitiba, Brazil, and stored under refrigeration $\left((4 \pm 2){ }^{\circ} \mathrm{C}\right)$ until further processing. The hydrocolloids used were: carrageenan, soy protein isolate, collagen (all Global Food, Sao Paulo, Brazil) and modified starch (Ingredion, Balsa Nova, Brazil). The brine solution of hydrocolloids consisted of sodium chloride (Reagen, Colombo, Brazil) and distilled water. Ether petroleum was purchased from Vetec (Duque de Caxias, Brasil). Thiobarbituric acid was obtained from Sigma-Aldrich, Merck (St. Louis, MO, USA). All reagents were of analytical grade.

\section{Proximate chemical composition}

Samples of the muscle vastus lateralis were used for the analysis of chemical composition. Moisture content was determined according to AOAC official method 950.46 (11). Approximately $10 \mathrm{~g}$ of the sample were weighed in a moisture dish and the mass was recorded. The dish was then placed in a hot air oven (model 420-2D; Nova Etica, Sao Paulo, Brazil) at $(105 \pm 2)^{\circ} \mathrm{C}$ until a constant mass was recorded. The samples were weighed again and the moisture content was then calculated from the following formula:

$$
w(\text { moisture })=\left(\frac{m_{1}-m_{2}}{m_{1}-m}\right) \cdot 100
$$

where $m$ is the mass of the empty dish $(\mathrm{g}), m_{1}$ is the initial mass of the dish containing the sample $(\mathrm{g})$, and $m_{2}$ is the final mass of the dish with the sample after drying ( $\mathrm{g}$ ).

The $\mathrm{pH}$ value was measured with a meat $\mathrm{pH}$ meter (model mCA-150; MS Tecnopon, Sao Paulo, Brazil) inserted into the raw meat.
The Kjeldahl method was used to determine the nitrogen content of the meat samples according to the following equation:

$$
w(\mathrm{~N})=\frac{V(\mathrm{HCl}) \cdot c(\mathrm{HCl}) \cdot 0.014 \cdot 100}{m(\text { sample })}
$$

Protein content was determined by multiplying the quantity of nitrogen by nitrogen-to-protein conversion factor 6.25 , as described in AOAC official method 928.08 (12). The fat mass fraction was determined by an ether petroleum extraction. Samples $(5 \mathrm{~g})$ were inserted into a fat extraction flask that had been previously weighed, it was connected to the Soxhlet apparatus (model SL 145/6; Solab, Sao Paulo, Brazil), and then subjected to a continuous extraction with ether petroleum for $6 \mathrm{~h}$. The fat extraction flask was then removed from the extractor and allowed to dry for $2 \mathrm{~h}$ at $40^{\circ} \mathrm{C}$ in a hot air oven (model 3/495; De Leo, Porto Alegre, Brazil) until no trace of ether petroleum remained. The fat content was determined from the obtained dry mass of moisture assay, according to the AOAC official method 960.39 (13).

Mineral residue content (14) was determined by heating the samples in a muffle furnace (model Q318 24; Quimis, Diadema, Brazil) at $550^{\circ} \mathrm{C}$ for $24 \mathrm{~h}$. Mineral residue was also gathered during the retorted control treatments with $\mathrm{NaCl} 2.5$ and $5.0 \%$.

\section{Brine solution of hydrocolloids prepared for retorting}

Sterilized beef was treated with a fixed $1.0 \%$ hydrocolloid and a brine volume fraction of $40 \%$. These set values were obtained from previous experiments of a $3^{2}$ factorial design to estimate the optimal hydrocolloid mass fraction and water volume for injection in beef (data not shown).

The brine solution containing hydrocolloids was prepared as follows: mass fraction of 2.5 or $5.0 \% \mathrm{NaCl}$ with 1.0 $\%$ hydrocolloid (except control, which did not contain a hydrocolloid) were weighted and solubilized with $40 \%$ of distilled water. After mixing, the solutions were stirred (model 6795-400D; Corning, Corning, NY, USA) for $10 \mathrm{~min}$ at $25^{\circ} \mathrm{C}$ and $1200 \mathrm{rpm}$.

The beef samples included treatments with carrageenan, soy protein isolate, collagen, modified starch and control. They were portioned in cubes $(3 \mathrm{~cm} \times 3 \mathrm{~cm} \times 3 \mathrm{~cm})$ of approx. $45 \mathrm{~g}$ and equal quantities separated according to each treatment. In addition, $\mathrm{NaCl}$ at mass fractions of 2.5 or $5.0 \%$ was added to all treatments to activate the salting-in effect.

Finally, the beef cubes were injected with the solutions and remained immersed in the respective solution for $12 \mathrm{~h}$ at $4{ }^{\circ} \mathrm{C}$. Then, the beef cubes were drained and vacuum-packed for sterilization, as described below.

\section{Thermal process evaluation}

The sterilization was performed in a water cascading retort (Ardode, Araquari, Brazil) operating at $121{ }^{\circ} \mathrm{C}$ and 0.150 $\mathrm{MPa}$, conditions similar to the commercially retorted meat products. After processing the pouches to the required $F_{0}$ 
value, they were cooled rapidly by pumping and recirculating water into the chamber until the core temperature of the product reached $30^{\circ} \mathrm{C}$.

For heat penetration studies, four pouches had the type $T$ thermocouples (Exacta, Sao Paulo, Brazil) inserted and sealed with a heat-resistant silicone, and they were fixed in different positions in the chamber to determine the lowest heating point of the meat cubes. Then, the temperature at the slowest heating point of the retort pouches was monitored. The thermocouple tips were inserted into the beef cubes positioned in the geometric centre of the pouch. Temperature outputs of the thermocouples were recorded every $60 \mathrm{~s}$, and sterility was expressed as an $F_{0}$ value, using the Simpson rule (15), calculated with the following equation:

$$
F_{0}=\int_{0}^{\tau} 10^{\left(\mathrm{t}-\mathrm{t}_{\mathrm{ref}}\right) / z} \delta \tau
$$

where $F_{0}$ is the calculated lethality value ( $\left.\mathrm{min}\right), t$ is the temperature of the thermocouple $\left({ }^{\circ} \mathrm{C}\right), t_{\text {ref }}$ is the reference temperature, $z$ is the temperature coefficient for microbial destruction $\left({ }^{\circ} \mathrm{C}\right)$, and $\tau$ is time $(\mathrm{min})$.

\section{Measurements of moisture, yield, water holding capacity and cooking loss}

Moisture, yield $(Y / \%)$, water-holding capacity (WHC/\%), and cooking loss $(\mathrm{CL} / \%)$ of the sterilized meat samples were analyzed before and after the sterilization. Moisture was evaluated according to AOAC (11) as mentioned earlier. The yield was determined by weighing the samples before and after the injection of the brine solution containing hydrocolloids, and cooking loss was calculated by weighing the drained beef cubes after sterilization.

Loss of mass during different stages of processing was carefully monitored through yield, cooking loss and the total mass loss. All losses were calculated as a percentage of mass taken prior to each processing stage.

Water-holding capacity measurement followed the proceduredescribedby Ayadietal.(16).About 10 gofeachcubesample was centrifuged (model Z323K; Hermle, Gosheim, Germany) at $10200 \times g$ for $30 \mathrm{~min}$ at $4{ }^{\circ} \mathrm{C}$. The water-holding capacity was calculated as a percentage of the bound water using the following equation:

$$
\mathrm{WHC}=\left(\frac{m_{\mathrm{ac}}}{m_{\mathrm{bc}}}\right) \cdot 100
$$

where $\mathrm{WHC}$ is the water-holding capacity (\%), $m_{\mathrm{ac}}$ is the mass of the beef sample after centrifugation, and $m_{\mathrm{bc}}$ is the mass of the sample before centrifugation.

\section{The shelf life of the sterilized beef}

The treatments that had the best yield, water-holding capacity and optimal cooking loss at $5.0 \% \mathrm{NaCl}$ were tested during 180 days of storage at $25^{\circ} \mathrm{C}$ in a refrigerator (model TE-391; Tecnal, Piracicaba, Brazil).
Samples were drained from the brine solutions and weighed before sterilization. In order to validate the efficiency of the sterilization in reducing contamination, sterilized samples $(500 \mathrm{~g}$ ) collected on the first day of storage were sent to an outsourced microbiology laboratory, where the following microbiology assays were performed: faecal coliforms according to Association Française de Normalisation (AFNOR) (17), enumeration of sulphite-reducing Clostridium according to ISO 15213:2003 (18), determination of Salmonella spp. and coagulase-positive Staphylococcus (19). Syneresis was evaluated according to Honikel (20). After sterilization, the pouches were opened each storage day, the exudate was drained from the samples and before weighing them again. The difference in the mass of the drained samples before and after sterilization was calculated as follows:

$$
\text { Syneresis }=\left(\frac{m_{\mathrm{as}}-m_{\mathrm{bs}}}{m_{\mathrm{bs}}}\right) \cdot 100
$$

where $m_{\text {as }}$ is the mass of the beef sample after sterilization, and $m_{\mathrm{bs}}$ is the mass of the sample before sterilization.

Water activity $\left(a_{\mathrm{w}}\right)$ was determined with a water activity meter model AquaLab CX-2 (Decagon Devices Inc., METTER Group, Pullman, WA, USA), using a controlled temperature of $(25 \pm 1)^{\circ} \mathrm{C}$.

The extent of lipid oxidation was assessed by analysis of the 2-thiobarbituric acid reactive substances (TBARS) using the distillation method described by Torres et al. (21). The TBARS values were expressed in mg malondialdehyde (MDA) per kg sample. Three samples of $(10 \pm 0.001) \mathrm{g}$ from each treatment were measured in sextuplicate.

\section{Texture profile analysis and shear force}

A double compression cycle test was performed (texture analyzer model CT3; AMETEK Brookfield, Middleborough, MA, USA) up to $50 \%$ compression of the original portion height with a nylon cylinder probe of $2 \mathrm{~cm}$ in diameter. Time of $1 \mathrm{~s}$ was allowed to elapse between the two compression cycles. Force-time deformation curves were obtained with a $25 \mathrm{~kg}$ load cell applied at a cross-head speed of $3 \mathrm{~mm} / \mathrm{s}$. The following parameters were quantified: hardness, cohesiveness, springiness, and chewiness.

The Warner-Bratzler shear force was measured using the method described by Wheeler et al. (22). Six cores of at least $2.5 \mathrm{~cm}$ length and $1.27 \mathrm{~cm}$ in diameter were excised from the cooked samples. The direction of muscle fibres was parallel to the longitudinal direction of the core. The cores were tested on a texture analyser (model CT3; AMETEK Brookfield) that had a $1 \mathrm{~mm}$ thick cutting V-shaped blade and speed of $3 \mathrm{~mm} / \mathrm{s}$ when cutting through the core. Shear force was recorded as peak force $(\mathrm{N})$.

\section{Sensory analysis}

Sensory analysis was performed according to the method described by Nicola (23). The samples were heated in a water 
bath at $100{ }^{\circ} \mathrm{C}$ until the temperature in the centre reached $70{ }^{\circ} \mathrm{C}$. For each sensory test, the meat samples were put on white, opaque plates and coded with three-digit numbers chosen randomly. All sessions were performed in a sensory analysis laboratory equipped with individual testing booths held at a constant temperature $\left(20^{\circ} \mathrm{C}\right)$, positive airflow removed any odours from the testing area and controlled lighting to neutralize any possible differences in colour or appearance of the meat. Saline water $(0.9 \% \mathrm{NaCl}$ solution at room temperature) was provided as a palate cleanser for rinsing the mouth and cleaning the tongue before testing each sample. To minimise the effect of tasting order, an equal number of plates with opposite sample order was prepared.

A paired preference test was conducted to assess if one of the two meat samples had more acceptable sensory characteristics, expressed as a generic preference. Assessors $(N=74)$ were asked to taste the two samples starting from the left side of the plate. After tasting, they were asked to express their meat taste preference. Since a forced-choice procedure was adopted, a sample was chosen even if the selection by the assessor was random. Each person made one or two independent tastings, with a different sample order if two tastings were made.

A triangle test was performed $(N=74)$ where judges were asked to detect any change in the taste and mouthfeel of the treated sample as compared to the changes in the control sample. Assessors were asked to smell and taste one different and two identical samples of meat in the same session and instructed to indicate the odd sample.

\section{Statistical analysis}

Analyses of the proximate composition, physicochemical characteristics, texture and shear force were performed in quadruplicate. Lipid oxidation was measured in sextuplicate. The results were reported as mean value \pm standard deviation. The differences between mean values were determined using analysis of variance (ANOVA) with Tukey's test $(p<0.05)$ and their statistical significance with the StatSoft STATISTICA v. 12.5.1 (24) software.

\section{RESULTS AND DISCUSSION}

\section{Proximate composition and $\mathrm{pH}$}

The findings of the proximate composition and other physicochemical parameters shown in Table 1 were found to be in line with other studies about vastus lateralis used as raw meat in meat products (4).

An increase in the sodium salts agitates the surface free energy of the protein-solvent interactions (25), whereas salt solubilizes the myofibrillar proteins in meat, which allows the proteins to increase hydration and the water-binding capacity. A review by Ruusunen and Puolanne (26) suggested a hypothesis to explain the role of $\mathrm{NaCl}$ in water-binding capacity in meat, chloride ions tend to penetrate the myofilaments causing them to swell (27), while Offer and Knight (28) and Offer and Trinick (29) claimed that the $\mathrm{Na}$ ions form an ion 'cloud' around the filaments.

Table 1. Compositional and physicochemical parameters of raw vastus lateralis meat

$\begin{array}{lcc}\text { Parameter } & & \text { Value } \\ w(\text { moisture }) / \% & & 73.0 \pm 1.1 \\ w(\text { fat }) / \% & & 5.7 \pm 0.5 \\ w(\text { protein }) / \% & & 21.6 \pm 0.8 \\ & & 1.04 \pm 0.04 \\ w(\text { mineral })_{\text {residual }} / \% & w(\mathrm{NaCl})_{\text {control }}=2.5 \% & 3.1 \pm 0.2 \\ & w(\mathrm{NaCl})_{\text {control }}=5.0 \% & 1.5 \pm 0.3 \\ \mathrm{pH} & & 5.80 \pm 0.07\end{array}$

Data represent mean value \pm S.D., $N=4$

As hypothesized, an increase of the mineral residue content was observed as the $\mathrm{NaCl}$ concentration increased, whereas the mineral content of the control samples with 2.5 and $5.0 \% \mathrm{NaCl}$ increased almost twofold, from (1.5 \pm 0.3$)$ to $(3.1 \pm 0.2) \%$ (Table 1). The purpose of adding salt was to promote its functional effect on the meat proteins, which would act in favour of the hydration of the beef proteins. However, since there is a limit to the salt mass fraction for the occurrence of these effects, two mass fractions were tested. The increase in mineral content reflected the water retention properties by meat samples, as discussed in the subsequent sections.

\section{Thermal process evaluation of sterilized meat samples}

The beef samples in the present study were sterilized for 30-35 min, resulting in an $F_{0}$ of $12.98 \mathrm{~min}$ (data not shown), in agreement with the $F_{0}$ range for meat products, which is $8-20$ min according to Footitt et al. (30).

Previous experiments have demonstrated that at first, the greater yield was reached as more brine volumes were used, but cooking loss was greater and water-holding capacity decreased. In addition, with more exudate, more moisture and nutrients are available to microorganisms, as observed in the post freeze/thaw process (31). Thus, the optimal conditions for sterilization process were $40 \%$ brine volume fraction and $1.0 \%$ hydrocolloid (data not shown).

Addition of brine to beef samples resulted in an increase in the yield, as observed for all treatments with both 2.5 (Table 2) and $5.0 \% \mathrm{NaCl}$ (Table 3). The hydrocolloid treatments gave at least $1 \%$ higher yield of the mass gain than control. Overall, the yield of meat was higher at $5.0 \%$ salt regardless of the treatment. Nonetheless, collagen had a significantly higher yield than control at $2.5 \%$ salt, whereas at $5.0 \% \mathrm{NaCl}$ collagen or soy protein isolate had greater yield than control $(p<0.05)$.

Cooking loss was the lowest in the samples treated with carrageenan and modified starch at $2.5 \%$ salt $(\mathrm{p}<0.05)$ (Table 2), while at $5.0 \%$ salt, no significant differences were 
Table 2. Physicochemical parameters of beef (vastus lateralis) cubes with added $1.0 \%$ hydrocolloid and $2.5 \%$ sodium chloride

\begin{tabular}{|c|c|c|c|c|c|c|c|}
\hline \multirow{2}{*}{ Hydrocolloid } & \multirow{2}{*}{$Y / \%$} & \multirow{2}{*}{$w(\mathrm{CL}) / \%$} & \multirow{2}{*}{$Y_{\text {total }} / \%$} & \multicolumn{2}{|c|}{$w($ moisture) $/ \%$} & \multicolumn{2}{|c|}{ WHC/\% } \\
\hline & & & & Before retort & After retort & Before retort & After retort \\
\hline Carrageenan & $(8.3 \pm 0.9)^{\mathrm{a}}$ & $(42.3 \pm 1.6)^{a}$ & -34.0 & $(77.0 \pm 1.5)^{\mathrm{a}, \mathrm{b}}$ & $(65.3 \pm 1.0)^{\mathrm{ab}}$ & $(53.3 \pm 0.2)^{\mathrm{a}}$ & $(82.0 \pm 0.3)^{\mathrm{a}}$ \\
\hline Soy protein isolate & $(7.7 \pm 1.7)^{\mathrm{a}}$ & $(44.6 \pm 0.7)^{\mathrm{ab}}$ & -36.8 & $(75.9 \pm 1.0)^{\mathrm{a}}$ & $(64.1 \pm 0.7)^{\mathrm{ab}}$ & $(66.1 \pm 2.0)^{\mathrm{b}}$ & $(86.9 \pm 2.4)^{\mathrm{b}}$ \\
\hline Collagen & $(20.0 \pm 5.1)^{\mathrm{b}}$ & $(47.0 \pm 2.9)^{b}$ & -27.0 & $(78.6 \pm 1.0)^{\mathrm{b}}$ & $(65.3 \pm 1.5)^{\mathrm{ab}}$ & $(73.1 \pm 4.8)^{c}$ & $(82.7 \pm 1.6)^{a}$ \\
\hline Modified starch & $(9.5 \pm 1.8)^{\mathrm{a}}$ & $(43.4 \pm 1.4)^{\mathrm{a}}$ & -33.9 & $(77.6 \pm 0.9)^{\mathrm{ab}}$ & $(66.4 \pm 1.8)^{a}$ & $(68.6 \pm 3.1)^{\mathrm{bc}}$ & $(82.3 \pm 1.1)^{\mathrm{a}}$ \\
\hline Control & $(7.3 \pm 1.0)^{a}$ & $(44.8 \pm 1.9)^{\mathrm{ab}}$ & -37.6 & $(78.3 \pm 0.8)^{\mathrm{ab}}$ & $(63.3 \pm 1.0)^{\mathrm{b}}$ & $(69.2 \pm 1.2)^{b c}$ & $(84.4 \pm 1.4)^{\mathrm{ab}}$ \\
\hline
\end{tabular}

Data represent mean value \pm S.D., $N=4$. Mean values in the same column with different letters in superscript are significantly different $(p<0.05)$ according to the Tukey's test. $Y=$ Yield, $\mathrm{CL}=$ cooking loss, $\mathrm{WHC}=$ water holding capacity. $Y_{\text {total }}=$ total yield obtained by subtracting yield with cooking loss

Table 3. Physicochemical parameters of beef (vastus lateralis) cubes with added $1.0 \%$ hydrocolloid and $5.0 \%$ sodium chloride

\begin{tabular}{|c|c|c|c|c|c|c|c|}
\hline \multirow{2}{*}{ Hydrocolloid } & \multirow{2}{*}{$Y / \%$} & \multirow{2}{*}{$w(\mathrm{CL}) / \%$} & \multirow{2}{*}{$Y_{\text {total }} / \%$} & \multicolumn{2}{|c|}{$w($ moisture $) / \%$} & \multicolumn{2}{|c|}{ WHC/\% } \\
\hline & & & & Before retort & After retort & Before retort & After retort \\
\hline Carrageenan & $(14.5 \pm 1.9)^{\mathrm{ab}}$ & $(43.3 \pm 3.9)^{\mathrm{ab}}$ & -28.8 & $(70.3 \pm 1.8)^{\mathrm{a}}$ & $(65.1 \pm 1.3)^{\mathrm{a}}$ & $(72.5 \pm 0.7)^{\mathrm{a}}$ & $(80.6 \pm 3.2)^{a}$ \\
\hline Soy protein isolate & $(16.0 \pm 2.2)^{\mathrm{a}}$ & $(43.1 \pm 2.4)^{\mathrm{ab}}$ & -27.1 & $(76.3 \pm 0.7)^{\mathrm{b}}$ & $(64.5 \pm 0.5)^{\mathrm{a}}$ & $(70.5 \pm 2.7)^{\mathrm{a}}$ & $(82.5 \pm 0.6)^{\mathrm{a}}$ \\
\hline Collagen & $(17.7 \pm 1.3)^{\mathrm{a}}$ & $(43.9 \pm 2.07)^{\mathrm{ab}}$ & -26.2 & $(74.5 \pm 1.4)^{\mathrm{b}}$ & $(63.1 \pm 2.5)^{\mathrm{a}}$ & $(71.8 \pm 4.1)^{\mathrm{a}}$ & $(78.9 \pm 0.6)^{\mathrm{a}}$ \\
\hline Modified starch & $(13.7 \pm 3.5)^{b}$ & $(41.0 \pm 1.28)^{\mathrm{a}}$ & -27.3 & $(74.5 \pm 2.3)^{\mathrm{ab}}$ & $(65.3 \pm 0.8)^{\mathrm{a}}$ & $(74.6 \pm 6.9)^{b}$ & $(83.7 \pm 2.5)^{\mathrm{a}}$ \\
\hline Control & $(11.6 \pm 1.3)^{b}$ & $(44.8 \pm 2.78)^{\mathrm{b}}$ & -33.2 & $(74.8 \pm 2.3)^{\mathrm{b}}$ & $(62.9 \pm 2.6)^{\mathrm{a}}$ & $(68.5 \pm 5.7)^{\mathrm{a}}$ & $(80.5 \pm 4.7)^{\mathrm{a}}$ \\
\hline
\end{tabular}

Data represent mean value \pm S.D., $N=4$. Mean values in the same column with different letters in superscript are significantly different $(p<0.05$ ) according to the Tukey's test. $Y=$ Yield, $\mathrm{CL}=$ cooking loss, $\mathrm{WHC}=$ water holding capacity. $Y_{\text {total }}=$ total yield obtained by subtracting yield with cooking loss

observed among the treatments (Table 3). As the yield was higher in meat samples treated with hydrocolloids, regardless of the salt mass fraction, similar cooking loss as in the control indicated that more water remained in the matrix even after the thermal treatment.

Hydrocolloids, such as the water-soluble polysaccharides, change their molecular conformation in aqueous media as a function of temperature $(1,8,9)$. The typical gel-forming hydrocolloids (e.g. agar, carrageenan, gellan and gelatin) undergo a molecular rearrangement (i.e. from random coil to a helicoidal state) as a prerequisite to gel formation. However, the created gel is under the influence of the kinetic control and the rate at which gelation is induced with the increase of temperature or the salt mass fraction (in systems where gelation is ion mediated) (32).

The yield of the samples treated with hydrocolloids was higher than of the control (Table 3). Hsu and Chung (33) found a higher yield in cooked emulsified meatballs with $20 \%$ water and $\mathrm{k}$-carrageenan and salt mass fractions of 1.6-2.0 and $1.8-2.2 \%$ respectively. Myofibrillar proteins have an essential water-binding role in meat products through, for example, the heat gelation process (32), and are influenced by factors such as salt mass fraction (ionic strength) and the presence of non-protein polymer ingredients $(26,34)$.

Total muscle protein comprises about $60 \%$ of the saltsoluble proteins (10). Chloride and sodium ions have a strong bond with myofibrils, shifting the net charges of the proteins that exert effects on hydration, such as salting in or salting out (26). The salting in effect, in which myofibrillar salt-soluble protein chains bind water molecules was observed by Offer et al. (28), who found that as the salt content of a salting solution increased above the physiological ionic strength of meat, there was a progressive increase in the amount of water-holding capacity.

Besides improvements in the water-holding capacity, the effect of salt ions (27) was at maximum level when ionic strength of the solution was $1.0 \mathrm{M}(5.8 \% \mathrm{NaCl})(29)$. The brine solutions used in this work were roughly $0.5 \mathrm{M}(2.5 \% \mathrm{NaCl})$ and $1 \mathrm{M}(5.0 \% \mathrm{NaCl})$, which provided an increase in the mineral content from $1.04 \%$ (raw meat) to $3.1 \%(5.0 \% \mathrm{NaCl})$ and had a synergistic effect with hydrocolloids on moisture retention (Table 1).

The salting in effect was evident in the yield of the control treatment, which increased from $7.3 \%$ when using $2.5 \%$ $\mathrm{NaCl}$ (Table 2) to $11.6 \%$ when using $5.0 \% \mathrm{NaCl}$ (Table 3). Much higher yield was obtained in beef samples treated with collagen, which was unexpected since gelatinization and loss of collagen have been reported above $80^{\circ} \mathrm{C}$ (3).

As seen in Table 3, part of the mass gain in treatments with hydrocolloids was maintained after the thermal treatment. The water-holding capacity values, which remained the same ( $p>0.05)$ compared to those of the control, displayed the mechanism by which hydrocolloids entrapped water inside the samples. The water that was incorporated in the matrix, which resulted in a higher yield, not only remained but was also deeply retained in the matrix. Ayadi et al. (16) showed that increasing the carrageenan mass fraction from 0 to $1.5 \%$ caused an increase in the water-holding capacity of about $1 \%$ in sausages. Even though higher yield was observed for all treatments (Table 3), there was no increase in $a_{w}$. This can be explained by the net charge difference promoted by the salting in effect (25). Since the structural proteins in meat cannot move, electrical forces pull the sodium ions very close to the filament surfaces, creating an uneven 
distribution of ions in the water phase. This establishes an osmosis-like force within the filament lattice, which in turn pulls water molecules into the system (26).

Partial loss of brine is expected before thermal processing, resulting in the loss of the injection volume retained within the matrix. McDonald et al. (35) found that all brine phosphate injections (20-45\%) in beef had similar cooking losses, suggesting that not all the phosphate and salt were incorporated into the samples. Sheard and Tali (36) injected $10 \%$ brine solutions at in pork loin and found that salt or bicarbonate alone had higher drip losses than those in the control samples.

However, most water in the muscle is held within the myofibrils (25). The bound water, which exists in the vicinity of non-aqueous constituents (like proteins) is very resistant to freezing and removal by conventional heating. In addition, entrapped water may be held either by steric (space) effects and/or by attraction to the bound water (25).

Therefore, the water is entrapped in the meat matrix due to salt solubilization and the functional properties of hydrocolloids. A study by Gou et al. (37) showed that pork ham samples soaked in $5 \mathrm{~kg} \mathrm{NaCl}$ per $100 \mathrm{~kg} \mathrm{H}_{2} \mathrm{O}$ had the highest moisture content on wet mass basis.

\section{Shelf life of retorted beef}

Treatments with collagen and modified starch at 5.0\% $\mathrm{NaCl}$ were chosen for shelf life analysis. The samples had the best overall values in all treatmens with $5.0 \%$ salt (Table 2 and Table 3). The choice of hydrocolloids was determined by total yield (Table 3). Total yield gives an overall aspect of which treatment can provide not only a higher yield, but also maintain the mass gain after the thermal treatment (33). Even though soy protein isolate had similar $(p>0.05)$ values to collagen and modified starch, for industrial purposes soy proteins are limited because of their relation to allergies (38). Therefore, the physicochemical evaluation was sufficient to assess the improvement of meat matrix properties by soy protein isolate addition, but further analysis would have not been relevant.

\section{Microbiological validation}

The obtained value of $F_{0}$ was capable of inactivating all bacteria present in the beef samples. The results for microbiology assays showed microbial counts lower than $10 \mathrm{CFU} / \mathrm{g}$ of faecal coliforms, Clostridium, Staphylococcus, and the absence of Salmonella. Retort processing in retort pouches reduces undesirable microorganisms (39), as reported by Rajan et al. (39) who observed that Chettinad chicken with an $F_{0}$ of 5.2 min did not have any E. coli, Salmonella spp., Clostridium spp., Staphylococcispp, yeast and mould during 180 days of storage.

\section{Syneresis and $a_{\mathrm{w}}$}

During the 180 days of storage, there was no significant difference ( $p>0.05$ ) in syneresis or $a_{w^{\prime}}$ regardless of the treatment or control (data not shown). Syneresis varied around 35-45 \%; samples treated with collagen had overall mean of $40.56 \%$, with modified starch $38.46 \%$, and control samples $40.49 \%$. The values of $a_{\mathrm{w}}$ in samples treated with collagen and modified starch were between $0.96-0.97$, whereas control had an $a_{\mathrm{w}}$ of 0.96 .

Cooking, as well as the presence of salt, influences the amount of water bound in the meat proteins. Cooking tends to reduce the $a_{w^{\prime}}$ as reported by Cheon et al. (5), where sterilized meatballs at temperatures between 117 and $125^{\circ} \mathrm{C}$ had an $a_{\mathrm{w}}$ of $0.96-0.99$. In contrast, $\mathrm{NaCl}$ was able to contribute to the water retention, fat-binding properties, flavour and texture. Moreover, $\mathrm{NaCl}$ has a preservative effect due to its ability to decrease the water activity (26).

Even though the addition of hydrocolloids may retain more water in the beef samples, the results of syneresis and $a_{\mathrm{w}}$ rely on the matrix hydration. Since the meat cubes remained inside the pouches with the water lost during sterilization, the matrix was continuously hydrated, resulting in no difference in the presence of hydrocolloids. Therefore, processing (sterilizing) and salting had more influence on the syneresis and $a_{\mathrm{w}}$ than the hydrocolloid itself. However, the hydrocolloid may have more influence if the product is not immersed in the solution.

Overall, for shelf life, there was no difference in the values of $a_{w}$ syneresis and lipid oxidation among all three evaluated treatments (control, collagen and modified starch). Therefore, the best treatment cannot be ranked based on a shelf life assessment.

\section{Lipid oxidation}

Sterilization temperatures reduce the lipid profile and composition of the matrix, depending on the heat and the imposed processing time $(39,40)$. High temperatures favour hydrolysis, reduce the energy activation for lipid oxidation, and decompose the pre-formed hydroperoxides into free radicals, which stimulate lipid oxidation and production of off-flavours (41), concentration of which can increase throughout storage (40).

However, sterilized meat products tend to have low lipid oxidation values, as seen in the present and prior studies $(42,43)$; lipid oxidation values expressed as malondialdehyde (MDA) ranged between 0.1 and $0.3 \mathrm{mgkg}$ of product (Fig. 1). Rajkumar et al. (42) described an increase in the oxidation values (as MDA) from 0.40 to $0.97 \mathrm{mg} / \mathrm{kg}$ of the product when meat lamb was sterilized at $121.1^{\circ} \mathrm{C}$ with an $F_{0}$ of $12.1 \mathrm{~min}$. Also, Muhlisin et al. (43) evaluated Chuncheon dakgalbi, a Korean chicken dish, sterilized at $110^{\circ} \mathrm{C}$ for $30 \mathrm{~min}$, and observed that product values expressed as thiobarbituric acid reactive substances (TBARS) were 1.65-2.59 mg/ $\mathrm{kg}$ and after three weeks increased to $3.64 \mathrm{mg} / \mathrm{kg}$.

The low oxidation values are associated with the lower effect of specific enzymes, as described by Nollet and Toldra (44) who observed that lipolysis could be driven by a series of enzymes, namely lipases, esterases and phospholipases, which can cleave the ester bond amid fatty acids and glycerol, resulting in the formation of free fatty acids. The extent 


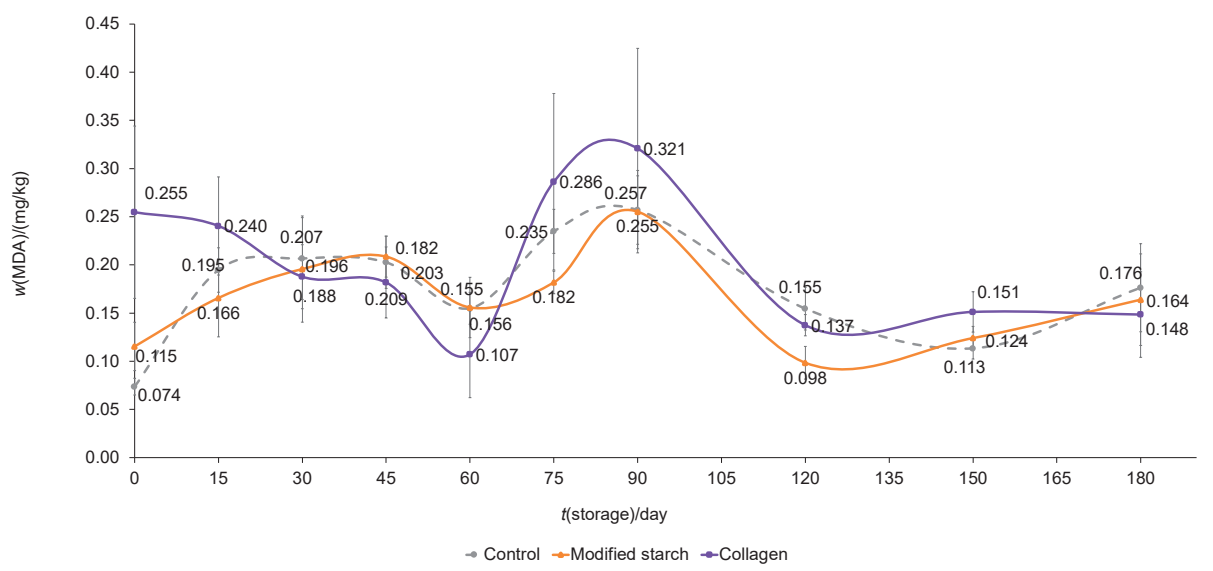

Fig. 1. Influence of the addition of modified starch (MS) or collagen (COL) on lipid oxidation expressed as malondialdehyde (MDA) during storage of the retorted beef. $C T R L=$ control. Data represent mean value $\pm S . D ., N=6$

and type of the process, such as dry-curing, ripening and fermenting can alter the extent of lipolysis and oxidation (44). Therefore, it can be proposed that the high sterilization temperatures are able to inactivate these enzymes, thus reducing or eliminating their functional properties.

Also, a shorter contact with oxygen favours the decrease in the TBARS values (39). The sterilized beef samples were vacuum packed in retort pouches composed of several layers to endure sterilization, which reduces oxygen permeability. Rajan et al. (39) observed a linear increase in lipid oxidation in retorted Chettinad chicken, which might be due to the residual oxygen as the pouches were not vacuum sealed. In addition, Güntensperger and Escher (45) observed a reduction of up to $80 \%$ in the sterilized ostrich meat $\left(F_{0}=8-9 \mathrm{~min}\right)$ when samples were stored under vacuum and modified atmosphere.

Lastly, hydrocolloids may affect oxidation, as reported by Milani and Maleki (46), who stated that hydrocolloids in a gel form could retard the moisture loss during a short-term storage, acting as a sacrificing agent rather than a barrier to moisture transmission. In some cases an inverse relationship between water vapour and oxygen permeability was observed, indicating that such films could provide an effective protection against lipid oxidation.

Texture profile, shear force and sensory properties of treates meat samples

Texture, shear force and sensory tests were made for the samples treated with collagen at $5.0 \% \mathrm{NaCl}$. Since collagen treatment gave the highest yield and $Y_{\text {total }}$ it is optimal choice to obtain the required physicochemical properties of meat required for the industry. The presence of collagen resulted in increased hardness and shear force compared to the control (Table 4). An increase in hardness and shear force values when using collagen depends on the temperature and collagen interaction with the matrix. Damodaran et al. (47) showed that collagen tended to form protein-protein bonds, which were stronger than the bonds between meat proteins.

In addition, temperatures above $60^{\circ} \mathrm{C}$ shorten the collagen fibres, which reduces the volume of muscular fibres and consequently, its hardness (48). In the range $80-120^{\circ} \mathrm{C}$, gelatinization of the soluble collagen led to a reduced fibre diameter and sarcomere length (3). In contrast, control samples were softer, with values of hardness and peak shear force of 21.5 and $21.2 \mathrm{~N}$, respectively. Palka (3) had similar values, $21.34 \mathrm{~N}$, for hardness of the sterilized beef without additives. Lower hardness values were also observed in sterilized short rib patties, with the lowest temperatures being $121-125^{\circ} \mathrm{C}(10)$.

The control samples received the highest number of preferences, with a statistically significant higher score $(p>0.05)$, with 46 preferences out of 74 . This may be due to lower hardness, shear force and chewiness values than for the samples treated with collagen (Table 4). Nonetheless, the panellists did not perceive the presence of collagen in the triangle test, whereas the number of incorrect answers was 48 out of the total 74 answers ( $p>0.05)$. Sensory analyses published by Prestes et al. (49) had no statistical differences when sausages with 1 and $4 \%$ collagen were compared to the control, showing that the addition of collagen made no difference to the panellists. Daigle et al. (50) stated that the addition of $0.3 \%$ carrageenan, $1.5 \%$ soy protein isolate or $1.5 \%$ collagen did not affect consumer acceptance of the pale, soft and exudative-like (PSE-like) turkey breast.

Table 4. Texture profile analysis and shear force of beef (vastus lateralis) cubes with $1.0 \%$ hydrocolloid and $5.0 \%$ sodium chloride

\begin{tabular}{|c|c|c|c|c|c|}
\hline Treatment & Hardness/N & Cohesiveness & Springness/mm & Chewiness/J & Peak shear force/N \\
\hline Control & $(21.5 \pm 6.5)^{\mathrm{a}}$ & $(0.25 \pm 0,02)^{a}$ & $(6.6 \pm 1.2)^{a}$ & $(20.2 \pm 2.6)^{a}$ & $(21.2 \pm 4.2)^{a}$ \\
\hline Collagen & $(60.3 \pm 18.8)^{b}$ & $(0.41 \pm 0.02)^{\mathrm{b}}$ & $(9.9 \pm 1.4)^{b}$ & $(211.6 \pm 36.9)^{b}$ & $(38.4 \pm 3.7)^{\mathrm{b}}$ \\
\hline
\end{tabular}

Data represent mean value \pm S.D., $N=4$. Mean values in the same column with different letters in superscript are significantly different ( $<<0.05$ ) according to the Tukey's test 


\section{CONCLUSIONS}

Retort provides a convenient, safe and ready-to-eat meat products. Nonetheless, high temperatures lower water holding capacity, influencing the texture, yield and water retention. Since there is a lack of studies that bypass the harmful effects of this technology, the present work studied the benefits of water-binding properties of hydrocolloids combined with salt on sterilized meat products. Results showed that even under the harsh conditions of sterilization, lipid oxidation (expressed as malondialdehyde) remained at low levels of $0.1-0.3 \mathrm{mg} / \mathrm{kg}$ during 180 days of storage. The addition of salt combined with hydrocolloids resulted in a higher yield, better water-holding capacity and minimized cooking loss due to a higher water retention. Treatment with $1 \%$ collagen and $5.0 \% \mathrm{NaCl}$ gave the highest yield (17.7\%), whereas control had $11.6 \%$. The addition of hydrocolloids did not influence water activity or syneresis levels of the product. However, samples treated with collagen had the best physicochemical results overall but also a harder and firmer meat than the control samples. Although sensory analysis showed a preference for control over the samples treated with collagen, panellists did not perceive the presence of collagen in the product. Retort technology can be improved by the addition of hydrocolloids combined with salt for the improvement of quality of the final product.

\section{ACKNOWLEDGEMENTS}

The authors acknowledge the support of AGRECO, MOTRICE and GLOBALFOOD for providing the equipment and materials needed for this work.

\section{FUNDING}

The authors duly acknowledge the financial support from the Government of Brazil under the National Funding Ministry CAPES project no. MCTI/CNPq 14/2014.

\section{CONFLICT OF INTEREST}

The authors declare that they have no conflict of interest.

\section{ORCID ID}

V.J. Bolognesi (1) https://orcid.org/0000-0002-4231-9242

M.R. Spier (1) https://orcid.org/0000-0002-7179-0586

C.E. Rocha Garcia (1) https://orcid.org/0000-0002-8213-1594

\section{REFERENCES}

1. Pasichnyi V, Ukrainets A, Shvedyuk D, Al-Hashimi HM, Matsuk Y. Determination of the optimal sterilization regime of canned quail meat with hydrocoloids application. EUREKA: Life Sci. 2017;4(4):21-5. https://doi.org/10.21303/2504-5695.2017.00379

2. Barbosa-Cánovas GV, Medina-Meza I, Candoğan K, Bermúdez-Aguirre D, Candogan K, Bermúdez-Aguirre D. Advanced retorting, microwave assisted thermal sterilization (MATS), and pressure assisted thermal sterilization (PATS) to process meat products. Meat Sci. 2014;98(3):420-34.

https://doi.org/10.1016/j.meatsci.2014.06.027

3. Palka K. Changes in intramuscular connective tissue and collagen solubility of bovine $m$. semitendinosus during retorting. Meat Sci. 1999;53(3):189-94.

https://doi.org/10.1016/S0309-1740(99)00047-9

4. Youssef EY, Rocha Garcia CE, Yamashita F, Shimokomaki M. Chemical basis for beef charqui meat texture. Braz Arch Biol Technol. 2007;50(4):719-24.

https://doi.org/10.1590/S1516-89132007000400018

5. Cheon HS, Choi SH, Jhin C, Cho WI, Choi JB, Shin HH, et al. Optimization of sterilization conditions for production of retorted meatballs. Food Sci Biotechnol. 2015;24(2):471-80. https://doi.org/10.1007/s10068-015-0062-7

6. Jang DH, Lee KT. Quality changes of ready-to-eat ginseng chicken porridge during storage at $25^{\circ} \mathrm{C}$. Meat Sci. 2012;92(4):469-73.

https://doi.org/10.1016/j.meatsci.2012.05.013

7. Ashwar BA, Gani A, Wani IA, Shah A, Masoodi FA, Chandra Saxena D. Production of resistant starch from rice by dual autoclaving-retrogradation treatment: Invitro digestibility, thermal and structural characterization. Food Hydrocoll. 2016;56:108-17.

https://doi.org/10.1016/j.foodhyd.2015.12.004

8. Zheng M, Su H, Luo M, Shen J, Zeng S, Zheng B, et al. Effect of hydrocolloids on the retrogradation of lotus seed starch undergoing an autoclaving-cooling treatment. J Food Sci. 2019;84(3):466-74.

https://doi.org/10.1111/1750-3841.14480

9. Hatakeyama T, lijima M, Hatakeyama H. Role of bound water on structural change of water insoluble polysaccharides. Food Hydrocoll. 2016;53:62-8.

https:// doi.org/10.1016/j.foodhyd.2014.12.033

10. Choi $\mathrm{SH}$, Cheigh $\mathrm{Cl}$, Chung MS. Optimization of processing conditions for the sterilization of retorted short-rib patties using the response surface methodology. Meat Sci. 2013;94(1):95-104.

https://doi.org/10.1016/j.meatsci.2012.12.016

11. AOAC Official Method 950.46. Moisture in meat. Rockville, MD, USA: AOAC International; 2005.

12. AOAC Official Method 928.08. Nitrogen in meat. Rockville, MD, USA: AOAC International; 2005.

13. AOAC Official Method 960.39. Fat (crude) or ether extract in meat. Rockville, MD, USA: AOAC International; 2005.

14. AOAC Official Method 920.153. Ash of meat. Rockville, MD, USA: AOAC International; 2005.

15. Holdsworth D, Simpson R. Thermal processing of packaged foods. Barbosa-Cánovas V, editor. Food Engineering Series. New York, NY, USA: Springer Science+Business, LLC; 2007. https://doi.org/10.1007/978-0-387-72250-4 
16. Ayadi MA, Kechaou A, Makni I, Attia H. Influence of carrageenan addition on turkey meat sausages properties. J Food Eng. 2009;93(3):278-83.

https://doi.org/10.1016/j.jfoodeng.2009.01.033

17. AFNOR Certificate Number $3 \mathrm{M}$ 01/2-09/89C. Loughborough, UK: 3M Health Care Ltd.; 2018.

18. ISO 15213:2003. Microbiology of food and animal feeding stuffs - Horizontal method for the enumeration of sulfitereducing bacteria growing under anaerobic conditions. Geneva, Switzerland: International Organization for Standardization (ISO); 2003.

19. AOAC Official Method 2011.03. Salmonella in a variety of food. Rockville, MD, USA: AOAC International; 2016.

20. Honikel KO. Reference methods for the assessment of physical characteristics of meat. Meat Sci. 1998;49(4):447-57.

https://doi.org/10.1016/S0309-1740(98)00034-5

21. Torres E, Pearson AM, Gray Jl, Ku PK, Shimokomaki M. Lipid oxidation in charqui (salted and dried beef). Food Chem. 1989;32(4):257-68.

https://doi.org/10.1016/0308-8146(89)90085-X

22. Wheeler TL, Shackelford SD, Koohmaraie M. Warner-Bratzler shear force protocol. Clay Center, NE, USA: USDA-ARS US Meat Animal Research Center; 2003. Available from: https://www.ars.usda.gov/ARSUserFiles/30400510/protocols/Warner-BratzlerShearForceProtocol.pdf.

23. Nicola RSM, editor. Sensorial analysis of foods. Curitiba, Brazil: PUCPRess - Editora Universitária Champagnat; 2015 (in Portuguese).

24. StatSoft Statistica, v. 12.5.1, TIBCO Software Inc, Palo Alto, CA, USA; 2013. Available from: https://www.tibco.com/ products/tibco-statistica.

25. Huff-Lonergan E, Lonergan SM. Mechanisms of water-holding capacity of meat: The role of postmortem biochemical and structural changes. Meat Sci. 2005;71(1):194-204.

https://doi.org/10.1016/j.meatsci.2005.04.022

26. Ruusunen $M$, Puolanne E. Reducing sodium intake from meat products. Meat Sci. 2005;70(3):531-41.

https://doi.org/10.1016/j.meatsci.2004.07.016

27. Hamm R. Colloidal chemistry of meat. In: Hamm R, editor. The water-binding capacity of the muscle in theory and practice. Berlin, Germany: Paul-Parey-Verlag; 1972 (in German).

28. Offer $G$, Knight $P$. The structural basis of water-holding in meat. Part 2: Drip loss. In: Lawrie R, editor. Development in meat science. London, UK: Elsevier Applied Science; 1988. pp. 172-243.

29. Offer G, Trinick J. On the mechanism of water holding in meat: The swelling and shrinking of myofibrils. Meat Sci. 1983;8(4):245-281. https://doi.org/10.1016/0309-1740(83)90013-X

30. Footitt RJ, Lewis AS, editors. The canning of fish and meat. Boston, MA, USA: Springer; 1995.

https://doi.org/10.1007/978-1-4615-2113-6
31. Leygonie C, Britz TJ, Hoffman LC. Impact of freezing and thawing on the quality of meat: Review. Meat Sci. 2012;91(2):93-8.

https://doi.org/10.1016/j.meatsci.2012.01.013

32. Norton IT, Foster TJ. Hydrocolloids in real food systems. In: Williams PA, Phillips GO, editors. Gums and stabilisers for the food industry 11. Cambridge, UK: RSC; 2007. pp. 187201.

https://doi.org/10.1039/9781847551016-00187

33. Hsu SY, Chung HY. Effects of k-carrageenan, salt, phosphates and fat on qualities of low fat emulsified meatballs. J Food Eng. 2001;47(2):115-21. https://doi.org/10.1016/S0260-8774(00)00106-0

34. Chin KB, Go MY, Xiong YL. Konjac flour improved textural and water retention properties of transglutaminase-mediated, heat-induced porcine myofibrillar protein gel: Effect of salt level and transglutaminase incubation. Meat Sci. 2009;81(3):565-72.

https://doi.org/10.1016/j.meatsci.2008.10.012

35. McDonald K, Sun DW, Kenny T. Effect of injection level on the quality of a rapid vacuum cooled cooked beef product. J Food Eng. 2001;47(2):139-47. https://doi.org/10.1016/S0260-8774(00)00110-2

36. Sheard PR, Tali A. Injection of salt, tripolyphosphate and bicarbonate marinade solutions to improve the yield and tenderness of cooked pork loin. Meat Sci. 2004;68(2):305-11. https://doi.org/10.1016/j.meatsci.2004.03.012

37. Gou P, Comaposada J, Arnau J. $\mathrm{NaCl}$ content and temperature effects on moisture diffusivity in the gluteus medius muscle of pork ham. Meat Sci. 2003;63(1):29-34. https://doi.org/10.1016/S0309-1740(02)00048-7

38. Sicherer SH, Sampson HA. Food allergy: Epidemiology, pathogenesis, diagnosis, and treatment. J Allergy Clin Immunol. 2014;133(2):291-307.

https://doi.org/10.1016/j.jaci.2013.11.020

39. Rajan S, Kulkarni VV, Chandirasekaran V. Preparation and storage stability of retort processed Chettinad chicken. J Food Sci Technol. 2014;51(1):173-7. https://doi.org/10.1007/s13197-011-0477-y

40. Bindu J, Ravishankar CN, Srinivasa Gopal TK. Shelf life evaluation of a ready-to-eat black clam (Villorita cyprinoides) product in indigenous retort pouches. J Food Eng. 2007;78(3):995-1000.

https://doi.org/10.1016/j.jfoodeng.2005.12.040

41. Min B, Ahn DU. Mechanism of lipid peroxidation in meat and meat products - A review. Food Sci Biotechnol. 2005;14(1):152-63.

42. Rajkumar V, Dushyanthan K, Das AK. Retort pouch processing of Chettinad style goat meat curry - A heritage meat product. J Food Sci Technol. 2010;47:372-9.

https://doi.org/10.1007/s13197-010-0062-9 
43. Muhlisin M, Kim DS, Song YR, Cho YJ, Kim CJ, An BK, et al. Effect of cooking time and storage temperature on the quality of home-made retort pouch packed Chuncheon Dakgalbi. Korean J Food Sci Anim Resour. 2013;33(6):737-43. https://doi.org/10.5851/kosfa.2013.33.6.737

44. Nollet LML, Toldra F. Handbook of processed meats and poultry analysis. Boca Raton, FL, USA: CRC Press; 2008. https://doi.org/10.1201/9781420045338

45. Güntensperger B, Escher FE. Oxidative changes of heatsterilized meat in trays. J Food Sci. 1994;59(4):689-92. https://doi.org/10.1111/j.1365-2621.1994.tb08105.x

46. Milani J, Maleki G. Hydrocolloids in food industry. In: Valdez $\mathrm{B}$, editor. Food industrial processes - Methods and equipment. Rijeka, Croatia: InTech; 2012. pp. 16-38.

https://doi.org/10.5772/32358
47. Damodaran S, Parkin KL, Fennema OR, editors. Fennema's food chemistry. Porto Alegre, Brazil: Artmed; 2010 (in Spanish).

48. Purslow PP. Intramuscular connective tissue and its role in meat quality. Meat Sci. 2005;70(3):435-47.

https://doi.org/10.1016/j.meatsci.2004.06.028

49. Prestes RC, Leite CVG, Kubota EH, Rosa CS, Kempka AP. Development of low fat chicken mortadella using collagen as a fat substitute. Int Food Res J. 2014;21(4):1651-7.

50. Daigle SP, Schilling MW, Marriott NG, Wang H, Barbeau WE, Williams RC. PSE-like turkey breast enhancement through adjunct incorporation in a chunked and formed deli roll. Meat Sci. 2005;69(2):319-24.

https://doi.org/10.1016/j.meatsci.2004.08.001 